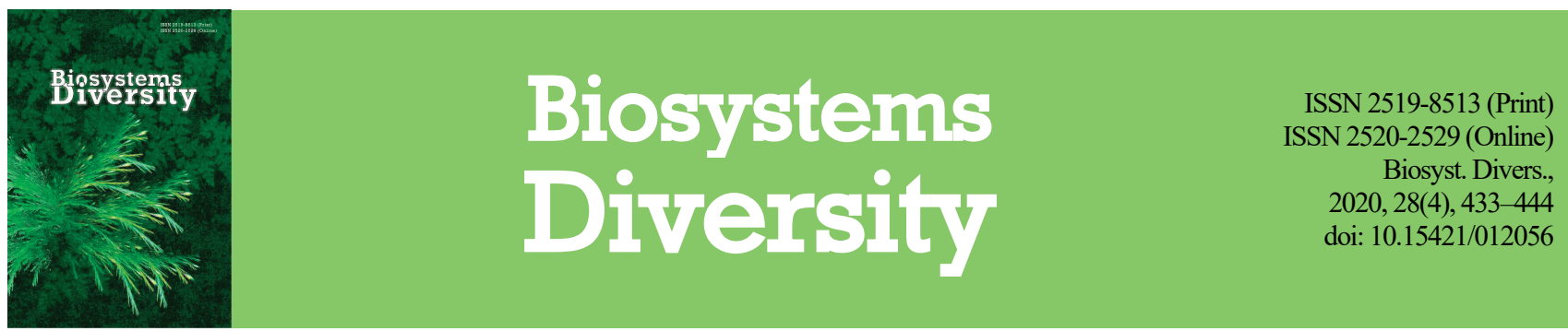

\title{
Time turnover of species in bird communities: the role of landscape diversity and climate change
}

\author{
O. I. Koshelev, V. O. Koshelev, M. P. Fedushko, O. V. Zhukov \\ Bogdan Khmelnitsky Melitopol State Pedagogical University, Melitopol, Ukraine
}

Article info

Received 08.10.2020

Received in revised form 01.11 .2020

Accepted 03.11.2020

Bogdan Khmelnitsk Melitopol State

Pedagogical University,

Hetmanska st., 20,

Melitopol, 72318, Ukraine

Tel.: +38-098-558-37-55.

E-mail:

aikoshelev4971@gmail.com

\begin{abstract}
Koshelev, O. I., Koshelev, V. O., Fedushko, M. P., \& Zhukov, O. V. (2020). Time turnover of species in bird communities: the role of landscape diversity and climate change. Biosystems Diversity, 28(4), 433-444. doi:10.15421/012056
\end{abstract}

The challenge of searching for patterns of species turnover dynamics in communities of living organisms is directly related to solving problems of stability and functioning of ecosystems. Avian communities are an essential structural and functional component of terrestrial and aquatic ecosystems which are highly diverse and play an important role in a wide range of ecosystem functions. The issue of changes in the dynamics of amphibiotic landscape complexes, where terrestrial and aquatic ecosystems conjugate, is practically not solved. In this connection, a study was carried out within a landscape system, which presents terrestrial and aquatic ecosystems that were in different degrees of anthropogenic transformation. The dynamics of bird communities was considered in the context of recent global climate change. The investigation was conducted in the landscapes of the south and south-east of Ukraine in the nesting seasons 1988-2018. Within the landscape system associated with the Molochny estuary, the ten most important types of ecosystems were distinguished, which included : agricultural lands, artificial forest belts, meadows, islands and spits, reed beds, urban areas, solonchaks, steppe, cliffs, artificial forests. The temporal turnover of the bird communities was decomposed into two parts: the first term (D1) related to the amount of change in community composition, and the second term (D2) being dependent only on the amount of change in community size sensu its abundance. The contribution ratio of the species and of the environment variable were calculated to identify drivers that influence the turnover measure. The average annual temperature and the sum of annual temperatures were considered as environment variables. The bird metacommunity of the studied landscape system was represented by 132 species from 86 genera, 42 families and 13 orders. During the research period the average annual temperature varied from 9.5 to $12.5^{\circ} \mathrm{C}$. and the temperature dynamics were subject to the linear trend. An oscillatory component was also present in the temperature dynamics. The annual rainfall ranged 220-761 mm. A coherent change in precipitation and temperature was observed in the period until 2011. After that, the temperature growth stabilized and the amount of precipitation began to fall sharply. The steppe bird community was represented by an extremely small number of species, but demonstrated the ability to maintain a stable structure for a long time. The main fluctuations of the community were quantitative changes in abundance, while the turnover of species was practically absent. Species of the community replace each other cyclically, but there were no targeted changes in community structure. Temperature and precipitation were the main drivers of the bird community in the steppe. The bird communities on salt marshes were characterized by a stable abundance, but a constant directed turnover of species. Reduced water levels and the disappearance of islands in the salt marshes increased the risk of threats from predators, which could lead to a decrease in the abundance of some species. The islands and spits were characterized by high species turnover with quasi-cyclical population dynamics. The main feature of the community dynamics was a decrease in the role of precipitation and an increase in the role of the time factor. The role of temperature remained stably low. The species richness of bird communities in agrarian lands was higher than in steppe communities. The turnover measure was significant because of the increased abundance of Alauda arvensis. Over time, the role of precipitation in the community dynamics has been decreasing and the role of time has been increasing. The value of temperature varied, but was at a stationary level. The turnover of species was compensated by an increase in the abundance of bird communities. The obtained results are in line with findings indicating that despite more stable land use intensities in recent years, climate change has not overtaken land use intensities as the main driver of bird population dynamics.

Keywords: ecosystem stability, temporal dynamic, estuary, beta-diversity, temperature, precipitation.

\section{Introduction}

Species communities are the best available variable to assess the response of both natural and anthropogenic ecosystems to environmental influences (Legendre \& Gauthier, 2014). Species live in ecosystems, and changes in their abundance in relation to changes in environmental conditions indicate the strength of the relationship between species and environment. This approach is a consequence of Hutchinson's niche theory (Hutchinson, 1957, 1965), according to which species are more likely to be found in places where they live in conditions that match their ecological preferences. The temporal dynamics of communities of living organisms are regulated by internal and external factors. Internal factors include intraspecific and interspecific interactions, colonization and extinction (Durant et al., 2014; Sokolov \& Zhukov, 2014; Marini et al., 2017; Márquez-Luna et al., 2019). External factors include processes initiated by pe- riodic disturbances and directed changes in environmental conditions (Connell \& Slatyer, 1977; Gonzalez \& Descamps-Julien, 2004; Brown \& Lawson, 2010; Lyons et al., 2013). Growing concern about threats to biodiversity highlights the need to quantify and understand temporal turnover (Dornelas et al., 2013). One approach to quantifying time turnover is to use indicators such as the Jacquard, Bray and Curtis indices (Bray \& Curtis, 1957), which were originally developed to measure the spatial changes. Time turnover has features such as unidirectional change that are not usually present in spatial $\beta$-diversity studies (Dornelas et al., 2013; Sokolov \& Zhukov, 2016, 2017). Moreover, time turnover is a consequence of community dynamics due to such processes as local immigration, dispersal, mortality, extinction, population growth and density dependence (Hanski, 1998).

Special attention was paid to measuring $\beta$-diversity in various spatial contexts. The concepts used to explain spatial changes in community 
structure such as extent, nestedness (Azeria et al., 2006), beta diversity (Anderson et al., 2011), taxonomic turnover (Legendre \& Gauthier, 2014) were applied to investigate the temporal patterns. Spatial and temporal turnovers are connected to each other through a stochastic sampling process. In turn, each type of turnover is affected by deterministic processes. The spatial partition of bird communities is suggested to be explained by their temporal dynamics (Barbe et al., 2018). The relative impact of deterministic processes decreases with the amount of primary productivity and increases with the heterogeneity of the environment (Stegen et al., 2013). The turnover of species in a community maintains ecosystem functions when species that reduce their abundance are substituted by species with similar functional roles (Srivastava \& Vellend, 2005; Loreau, 2010). Ecosystems are more stable when their diversity is higher, as more species can compensate for any changes that occur (Doak et al., 1998; Lehman \& Tilman, 2000). The temporal asynchrony in species abundance can help stabilize the community (Loreau, 2010). However, the number of species does not always change asynchronously and abundance of species in natural communities, as a rule, is subject to positive covariance. The absence of compensatory dynamics is due to the fact that abiotic factors may be more significant than competition (Houlahan et al., 2007). The theory predicts that the spatial turnover should be determined, in part, by the time turnover by reducing the probability of re-sampling of this species at high time turnover. However, this assumption requires its verification (Steiner \& Leibold, 2004)

The factors leading to the turnover of community species composition both in space and time might be stochastic (e.g., sampling and priority effects) or deterministic (e.g., competition and environmental filtering) (Stegen et al., 2013). Stochastic processes, such as neutral dynamics (Hubbell, 2005), are able to explain a part of the variation in species richness and community diversity (Gotelli \& Ulrich, 2012). The high proportion of the bird assemblage can be explained by chance, suggesting that most of the variations in the local bird community are due to stochastic processes (Renner et al., 2014). The importance of different assembly factors may also be subject to change over time (Chalcraft et al., 2004). The influence of primary productivity on community turnover was shown (Waide et al., 1999; Coelho et al., 2019; Moraitis \& Karakassis, 2020). The species turnover plays an important role in the formation of the species-richnessproductivity relationship (Chalcraft et al., 2004). Climatic changes affect species distribution and abundance (Parmesan \& Yohe, 2003). Habitat and climate variability affect the pattern of species diversity, from the relatively local scale of communities to the wide biogeographic scale of continents (Bradbury et al., 2005; Veech \& Crist, 2007; Goetz et al., 2010; Lewthwaite et al., 2017). Habitat heterogeneity affects diversity by significantly altering the relative proportions of species in contrasting habitat types (Cramer \& Willig, 2005). Habitat loss and fragmentation are considered the main drivers of species extinction. These factors significantly affect the temporal dynamics of bird communities (Blandón et al., 2016). Factors that determine the turnover of species between years include extreme weather events (Stouffer et al., 2011). Climate change leads to populations of species associated with warmer conditions having stable or growing populations, while populations associated with cooler climates are declining (Jiguet et al., 2007, 2010; Moller et al., 2008; Gregory et al., 2009; Davey et al., 2010).

Anthropogenic activities have an impact on bird species turnover $(\mathrm{La}$ Sorte \& Boecklen, 2005). The intensification of land use has led to a significant decline in bird diversity (Fischer \& Lindenmayer, 2007; Flynn et al., 2009; Eglington \& Pearce-Higgins, 2012). The increase in management intensity enhances the role of deterministic processes, since only species adapted to high land use intensities can persist in conditions of anthropogenic impact (Renner et al., 2014). The functional redundancy of the communities is reduced under conditions of land use intensification which might also decrease the importance of random processes in driving community composition (Laliberte et al., 2010). The decline in the number of farm birds across Europe was due to changes in land use and management associated with increased agricultural intensification (Chamberlain et al., 2000; Donald et al., 2001; Gregory et al., 2004; Sanderson et al., 2013). The effect of low-intensity land use largely depends on the amount of forests in the surrounding landscape. The increase in low-intensity land use was associated with an increase in species richness of bird communi- ties on the plots located in open agricultural lands, but resulted in a decrease in species richness on the plots located in the forest environment (Wretenberg et al., 2010).

The analysis of long-term bird community composition data sets showed that most of the temporal variability can be attributed to slow changes over many years (Kampichler et al., 2014). Anthropogenic stress was recognized to increase short-term temporal variability of ecological communities (Angeler et al., 2009; Hillebrand et al., 2010). This increase in the temporal variability of ecological systems can even be used as an early warning signal for impending catastrophic regime shifts in ecosystems (Carpenter \& Brock, 2006).

Thus, the problem of studying the regularities of species turnover dynamics in communities of living organisms is directly related to addressing issues of stability and ecosystem functioning. Bird communities are an essential structural and functional component of terrestrial and aquatic ecosystems that are highly diverse and play an important role in a wide range of ecosystem functions. The problem of dynamics of amphibiotic landscape complexes, where terrestrial and aquatic ecosystems are conjoined, has practically no solution. In this regard, we have conducted a study within a landscape system where land and water ecosystems which are in different degrees of anthropogenic transformation are represented. The dynamics of bird communities are considered in the context of global climate change which has been observed recently. Therefore, the purpose of this study is to identify the role of landscape diversity in the dynamics of bird communities and the role of climate factors as drivers of the turnover of species.

\section{Material and methods}

The investigation was conducted in the landscapes of the south and south-east of Ukraine in the nesting seasons 1988-2018. Within the landscape system associated with the Molochny estuary, the ten most important types of ecosystems were distinguished, which included agricultural lands, artificial forest belts, meadows, islands and spits, reed beds, urban areas, solonchaks, steppe, cliffs, artificial forests. The Molochny estuary is located within the north-western coast of the Azov Sea (46 $33^{\prime} \mathrm{N}$, $\left.35^{\circ} 24^{\prime \prime} \mathrm{E}\right)$. It is a shallow water body stretching from north to south. The maximum length is $36 \mathrm{~km}$, the largest width is $9 \mathrm{~km}$ in the southern part and the smallest is $4 \mathrm{~km}$ in the middle part of the water area. The total area of the estuary along the shoreline at the maximum water level is 21,945 thousand hectares. The Molochnaya River flows into the northern part, forming a delta with several branches. The southern part of the estuary is separated from the Azov Sea by the entire body of the spit Peresyp, composed of sand and shell sediments (Vorovka \& Demchenko, 2019). The Molochny estuary is one of the water bodies of the Azov group of estuaries which belongs to the closed type, ie, has no wide exchange of water masses with the sea. But, unlike completely closed reservoirs, the Molochny estuary is periodically connected to the Sea of Azov through an artificially created channel. The average depth is $1.5-2.0$ meters. Water salinity depends on the season, precipitation and the degree of isolation of the liman from the sea. In the years of strong desalination, the salinity decreases to 4-7 g/L, and in low-water periods, the salinity of the Molochny estuary water sharply increases. Information about temperature and precipitation at the Henichesk weather station was obtained from the National Climatic Data Center.

Two main methods of ornithological surveys were applied to collect data: on transect and point. The width of the survey corridors with good visibility was $7-8 \mathrm{~km}$, during rain $-2-4 \mathrm{~km}$, in fog - up to $500 \mathrm{~m}$ (in the specified boundaries it was maximum for larger species, and minimal for small birds and individuals which were in closed habitats with limited view). Point surveys were held during stops during the counts on monotonous open areas. In all cases, the territory was examined using $12-\mathrm{X}$ binoculars and 60-X telescopes. Depending on the duration of the day and the quality of the illumination counting was carried out throughout the daylight hours from 7:00-7:30 to 15:30-16:00. The counts were recorded to special cards, applied to the scale of 1:200,000 maps, and then transferred to the geographic information database created in the software ArcMap 10.0.

The temporal turnover (D) was suggested to be additively decomposed into two parts: the first term (D1) related to the amount of change in 
community composition, and the second term (D2) being dependent only on the amount of change in community size sensu its abundance (Shimadzu et al., 2015). This fact highlights two important aspects in evaluating the turnover of species community: 1) change in community composition and 2) change in total abundance. The turnover measure of the community between times $t$ and $u,(u>t)$ was defined as (Shimadzu et al., 2015):

$$
\begin{aligned}
D(t: u) & =-\sum_{i=1}^{x} \log \left(\frac{p_{i}(t)}{p_{i}(u)}\right) p_{i}(t)+\log \left(\frac{\lambda(u)}{\lambda(t)}\right) \\
& =D_{1}(p(t): p(u))+D_{z}(\lambda(t): \lambda(u)) .
\end{aligned}
$$

where $p_{i}(t)$ is the relative abundance of the $i$-th species at time $t, p_{i}(u)-$ is the relative abundance of the $i$-th species at time $u, \lambda(t)$ is the expected total-abundance of the species in the community at time $t, \lambda(u)$ is the expected total-abundance of the species in the community at time $u$. The first term, D1, may be interpreted as the part evaluating the compositional change of the community and the second term, D2, may be interpreted as

Table 1

Taxonomic diversity and presence of the aviafauna species (Class Aves) the part evaluating the change in total abundance. The expected value of $\lambda_{i}(t)$ was modeled in relation to the mean annual temperature. total annual precipitation and time variable (sequence of years). The generalised linear models (GLMs) were used to find the relationship between abundance and environmental factors (McCullagh \& Nelder, 1989). The contribution ratio of the $\mathrm{i}$-species and of the $\mathrm{j}$-th environment variable were calculated to identify drivers that influence the turnover measure, D. Statistical analysis conducted in Statistica 10.0.

\section{Results}

The bird metacommunity of the studied landscape system was represented by 132 species from 86 genera, 42 families and 13 orders (Table 1 ). The number of species in different types of habitats ranged from 4 (mea-

\begin{tabular}{|c|c|c|c|c|c|c|c|c|c|c|}
\hline \multirow{2}{*}{ Taxons } & \multicolumn{10}{|c|}{ Biotope* } \\
\hline & 1 & 2 & 3 & 4 & 5 & 6 & 7 & 8 & 9 & 10 \\
\hline \multicolumn{11}{|l|}{ Parvclass Galloanserae } \\
\hline \multicolumn{11}{|l|}{ Ordo Anseriformes } \\
\hline \multicolumn{11}{|l|}{ Family Anatidae } \\
\hline Anas clypeata Linnaeus, 1758 & - & - & - & - & + & - & - & - & - & - \\
\hline Anas platyrhynchos Linnaeus, 1758 & - & + & - & + & + & - & - & - & - & - \\
\hline Anas querquedula Linnaeus, 1758 & - & - & - & + & + & - & - & - & - & - \\
\hline Anas strepera Linnaeus, 1758 & - & + & - & + & + & - & - & - & - & - \\
\hline Anser anser (Linnaeus, 1758) & - & - & - & + & + & - & - & - & - & - \\
\hline Aythya ferina (Linnaeus, 1758) & - & - & - & - & + & - & - & - & - & - \\
\hline Aythya nyroca (Guldenstadt, 1770) & - & - & - & - & + & - & - & - & - & - \\
\hline Bucephala clangula (Linnaeus, 1758) & - & - & - & - & + & - & - & - & - & - \\
\hline Cygnus olor (Gmelin, 1803) & - & - & - & - & + & - & - & - & - & - \\
\hline Netta rufina (Pallas, 1773) & - & - & - & - & + & - & - & - & - & - \\
\hline Tadorna ferruginea (Pallas, 1764) & - & - & - & - & + & - & - & - & - & - \\
\hline Tadorna tadorna (Linnaeus, 1758) & - & - & - & + & + & - & - & - & + & - \\
\hline \multicolumn{11}{|l|}{ Ordo Galliformes } \\
\hline \multicolumn{11}{|l|}{ Family Phasianidae } \\
\hline Coturnix coturnix (Linnaeus, 1758) & + & + & - & - & - & - & - & - & - & - \\
\hline Perdix perdix (Linnaeus, 1758) & - & + & - & + & - & - & - & - & - & + \\
\hline Phasianus colchicus Linnaeus, 1758 & - & + & - & - & + & - & - & - & - & + \\
\hline \multicolumn{11}{|l|}{ Parvclass Passerae } \\
\hline \multicolumn{11}{|l|}{ Ordo Charadriiformes } \\
\hline \multicolumn{11}{|l|}{ Family Scolopacidae } \\
\hline Tringa totanus (Linnaeus, 1758) & - & - & - & + & - & - & + & - & - & - \\
\hline \multicolumn{11}{|l|}{ Family Burhinoidea } \\
\hline Burhinus oedicnemus (Linnaeus, 1758) & + & - & - & - & - & - & - & - & - & - \\
\hline \multicolumn{11}{|l|}{ Family Charadriidae } \\
\hline Charadrius alexandrinus Linnaeus, 1758 & - & - & - & + & - & - & + & - & - & - \\
\hline Charadrius dubius Scopoli, 1786 & - & - & - & + & - & - & + & - & - & - \\
\hline Vanellus vanellus (Linnaeus, 1758) & - & - & - & + & + & - & + & - & - & - \\
\hline \multicolumn{11}{|l|}{ Family Haematopodidae } \\
\hline $\begin{array}{l}\text { Haematopus ostralegus Linnaeus, } 1758 \\
\text { Family Laridae }\end{array}$ & \multicolumn{9}{|c|}{ Family Laridae } & - \\
\hline Larus cachinnans Pallas, 1811 & - & - & - & + & - & - & - & - & - & - \\
\hline Larus genei Breme, 1840 & - & - & - & + & - & - & - & - & - & - \\
\hline Larus melanocephalus Temminck, 1820 & - & - & - & + & - & - & - & - & - & - \\
\hline Sterna albifrons Pallas, 1764 & - & - & - & + & - & - & + & - & - & - \\
\hline Sterna hirundo Linnaeus, 1758 & - & - & - & + & + & - & + & - & - & - \\
\hline Sterna nilotica Gmelin, 1789 & - & - & - & + & - & - & - & - & - & - \\
\hline Sterna sandvicensis Latham, 1787 & - & - & - & + & - & - & - & - & - & - \\
\hline \multicolumn{11}{|l|}{ Family Recurvirostridae } \\
\hline Himantopus himantopus (Linnaeus, 1758) & - & - & - & + & - & - & + & - & - & - \\
\hline Recurvirostra avosetta Linnaeus, 1758 & - & - & - & + & + & - & + & - & - & - \\
\hline Ordo Ciconiiformes & & & & & & & & & & \\
\hline Family Phalacrocoracidae & & & & & & & & & & \\
\hline Phalacrocorax carbo (Linnaeus, 1758) & - & - & - & + & - & - & - & - & - & - \\
\hline Family Podicipitidae & & & & & & & & & & \\
\hline Podiceps cristatus (Linnaeus, 1758) & - & - & - & + & + & - & - & - & - & - \\
\hline Podiceps grisegena (Boddaert, 1783) & - & - & - & - & + & - & - & - & - & - \\
\hline Tachybaptus ruficollis (Pallas, 1764) & - & - & - & - & + & - & - & - & - & - \\
\hline Family Ardeidae & & & & & & & & & & \\
\hline Ardea cinerea Linnaeus, 1758 & - & - & - & + & + & - & - & - & - & - \\
\hline Ardea purpurea Linnaeus, 1766 & - & - & - & - & + & - & - & - & - & - \\
\hline Botaurus stellaris (Linnaeus, 1758) & - & - & - & - & + & - & - & - & - & - \\
\hline Casmerodius albus (Linnaeus, 1758) & - & - & - & + & + & - & - & - & - & - \\
\hline Egretta garzetta (Linnaeus, 1758) & - & + & - & - & + & - & - & - & - & - \\
\hline Ixobrychus minutus (Linnaeus, 1766) & - & - & - & + & + & - & - & - & - & - \\
\hline
\end{tabular}
dows) to 55 (artificial forests, Table 2). 


\begin{tabular}{|c|c|c|c|c|c|c|c|c|c|c|}
\hline \multirow{2}{*}{ Taxons } & \multicolumn{10}{|c|}{ Biotope* } \\
\hline & 1 & 2 & 3 & 4 & 5 & 6 & 7 & 8 & 9 & 10 \\
\hline
\end{tabular}

Family Threskiornithidae

Plegadis falcinellus (Linnaeus, 1766)

Ordo Columbiformes

Family Columbidae

Columba oenas Linnaeus, 1758

Streptopelia decaocto (Frivaldszky, 1838)

Streptopelia turtur (Linnaeus, 1758)

Ordo Coraciiformes

Family Alcedinidae

Alcedo atthis (Linnaeus, 1758)

Family Coraciidae

Coracias garrulus Linnaeus, 1758

Family Meropidae

Merops apiaster Linnaeus, 1758

Ordo Cuculiformes

Family Cuculidae

Cuculus canorus Linnaeus, 1758

Ordo Falconiformes

Family Accipitridae

Accipiter gentilis (Linnaeus, 1758)

Buteo buteo (Linnaeus, 1758)

Buteo rufinus (Cretzschmar, 1827)

Circus aeruginosus (Linnaeus, 1758) Family Falconidae

Falco columbarius Linnaeus, 1758

Falco subbuteo Linnaeus, 1758

Falco tinnunculus Linnaeus, 1758

Falco vespertinus Linnaeus, 1766

Ordo Gruiformes

Family Rallidae

Fulica atra Linnaeus, 1758

Gallinula chloropus (Linnaeus, 1758)

Porzana parva (Scopoli, 1769)

Porzana porzana (Linnaeus, 1766)

Rallus aquaticus Linnaeus, 1758

Ordo Passeriformes

Family Alaudidae

Alauda arvensis Linnaeus, 1758

Calandrella rufescens (Vieillot, 1820)

Galerida cristata (Linnaeus, 1758)

Lullula arborea (Linnaeus, 1758)

Melanocorypha calandra (Linnaeus, 1766) Family Corvidae

Corvus corax Linnaeus, 1758

Corvus cornix Linnaeus, 1758

Corvus frugilegus Linnaeus, 1758

Corvus monedula Linnaeus, 1758

Garrulus glandarius (Linnaeus, 1758)

Pica pica (Linnaeus, 1758)

Family Emberizidae

Emberiza calandra Linnaeus, 1758

Emberiza citrinella Linnaeus, 1758

Emberiza hortulana Linnaeus, 1758

Emberiza schoeniclus (Linnaeus, 1758) Family Fringillidae

Carduelis cannabina (Linnaeus, 1758)

Carduelis carduelis (Linnaeus, 1758)

Chloris chloris (Linnaeus, 1758)

Coccothraustes coccothraustes (Linnaeus, 1758)

Fringilla coelebs Linnaeus, 1758 Family Hirundinidae

Hirundo rustica Linnaeus, 1758

Riparia riparia (Linnaeus, 1758) Family Laniidae

Lanius collurio Linnaeus, 1758

Lanius minor Gmelin, 1788

Family Motacillidae

Anthus campestris (Linnaeus, 1758)

Anthus trivialis (Linnaeus, 1758)

Motacilla alba Linnaeus, 1758

Motacilla citreola Pallas, 1776

Motacilla feldegg Michahelles, 1830

Motacilla flava Linnaeus, 1758

Family Muscicapidae

Ficedula albicollis (Temminck, 1815)

Muscicapa striata (Pallas, 1764)

Family Oriolidae

Oriolus oriolus (Linnaeus, 1758) 


\begin{tabular}{|c|c|c|c|c|c|c|c|c|c|c|}
\hline \multirow{2}{*}{ Taxons } & \multicolumn{10}{|c|}{ Biotope* } \\
\hline & 1 & 2 & 3 & 4 & 5 & 6 & 7 & 8 & 9 & 10 \\
\hline Family Paridae & & & & & & & & & & \\
\hline Parus caeruleus Linnaeus, 1758 & - & + & - & - & - & - & - & - & - & + \\
\hline $\begin{array}{l}\text { Parus major Linnaeus, } 1758 \\
\text { Family Passeridae }\end{array}$ & - & + & - & - & - & - & - & - & - & + \\
\hline Passer domesticus (Linnaeus, 1758) & - & - & - & - & - & + & - & - & - & + \\
\hline $\begin{array}{l}\text { Passer montanus (Linnaeus, 1758) } \\
\quad \text { Family Remizidae }\end{array}$ & - & + & - & - & - & - & - & - & + & + \\
\hline $\begin{array}{l}\text { Remiz pendulinus (Linnaeus, 1758) } \\
\text { Family Saxicolidae }\end{array}$ & - & + & - & - & - & - & - & - & - & - \\
\hline Erithacus rubecula (Linnaeus, 1758) & - & - & - & - & - & - & - & - & - & + \\
\hline Luscinia luscinia (Linnaeus, 1758) & - & - & - & - & - & - & - & - & - & + \\
\hline Luscinia svecica (Linnaeus, 1758) & - & - & - & - & + & - & - & - & - & - \\
\hline Oenanthe isabellina (Temminck, 1829) & + & - & - & - & - & - & - & + & - & - \\
\hline Oenanthe oenanthe (Linnaeus, 1758) & + & - & - & - & - & + & - & - & - & - \\
\hline Phoenicurus phoenicurus (Linnaeus, 1758) & - & + & - & - & - & - & - & - & - & + \\
\hline $\begin{array}{l}\text { Saxicola torquatus (Linnaeus, 1766) } \\
\text { Family Sturnidae }\end{array}$ & - & - & + & - & - & - & - & - & - & - \\
\hline $\begin{array}{l}\text { Sturnus vulgaris Linnaeus, } 1758 \\
\text { Family Sylviidae }\end{array}$ & - & + & - & - & - & + & - & - & + & + \\
\hline Acrocephalus agricola (Jerdon, 1845) & - & - & - & + & + & - & - & - & - & - \\
\hline Acrocephalus arundinaceus (Linnaeus, 1758) & - & - & - & + & + & - & - & - & - & - \\
\hline Acrocephalus scirpaceus (Hermann, 1804) & - & - & - & - & + & - & - & - & - & - \\
\hline Hippolais icterina (Vieillot, 1817) & - & - & - & - & - & - & - & - & - & + \\
\hline Locustella luscinioides (Savi, 1824) & - & - & - & + & + & - & - & - & - & - \\
\hline Panurus biarmicus (Linnaeus, 1758) & - & - & - & + & + & - & - & - & - & - \\
\hline Phylloscopus collybita (Vieillot, 1887) & - & - & - & - & - & - & - & - & - & + \\
\hline Phylloscopus trochilus (Linnaeus, 1758) & - & + & - & - & - & - & - & - & - & + \\
\hline Sylvia atricapilla (Linnaeus, 1758) & - & - & - & - & - & - & - & - & - & + \\
\hline Sylvia borin (Boddaert, 1783) & - & - & - & - & - & - & - & - & - & + \\
\hline Sylvia communis Latham, 1787 & - & + & - & - & - & - & - & - & - & + \\
\hline $\begin{array}{l}\text { Sylvia nisoria (Bechstein, 1795) } \\
\text { Family Turdidae }\end{array}$ & - & + & - & - & - & - & - & - & - & + \\
\hline Turdus merula Linnaeus, 1758 & - & + & - & - & - & - & - & - & - & + \\
\hline $\begin{array}{l}\text { Turdus philomelos C. L. Brehm, } 1831 \\
\text { Ordo Picimorphes } \\
\text { Family Picidae }\end{array}$ & - & - & - & - & - & - & - & - & - & + \\
\hline Dendrocopos major (Linnaeus, 1758) & - & - & - & - & - & - & - & - & - & + \\
\hline Dendrocopos minor (Linnaeus, 1758) & - & - & - & - & - & - & - & - & - & + \\
\hline Dendrocopos syriacus (Hemprich \& Ehrenberg, 1833) & - & + & - & - & - & + & - & - & - & + \\
\hline $\begin{array}{l}\text { Jynx torquilla Linnaeus, } 1758 \\
\text { Ordo Strigiformes } \\
\text { Family Caprimulgidae }\end{array}$ & - & + & - & - & - & - & - & - & - & + \\
\hline $\begin{array}{l}\text { Caprimulgus europaeus Linnaeus, } 1758 \\
\text { Family Strigidae }\end{array}$ & - & + & - & - & - & - & - & - & - & + \\
\hline Asio flammeus (Pontoppidan, 1763) & - & + & - & - & - & - & - & - & - & + \\
\hline Asio otus (Linnaeus, 1758) & - & + & - & - & - & - & - & - & - & + \\
\hline Athene noctua (Scopoli, 1769) & - & - & - & - & - & - & - & - & + & - \\
\hline $\begin{array}{l}\text { Otus scops (Linnaeus, 1758) } \\
\text { Ordo Upupiformes } \\
\text { Family Upupidae }\end{array}$ & - & + & - & - & - & - & - & - & - & + \\
\hline Upupa epops Linnaeus, 1758 & - & - & - & + & - & + & - & - & + & + \\
\hline
\end{tabular}

Note: 1 -agricultural lands; 2 -artificial forest belt; 3 - meadows; 4 - islands and spits; 5 -reed beds; 6 -urban areas; 7 -solonchaks; 8 -steppe; 9-cliff; 10 -artificial forests.

During the research period the average annual temperature varied from 9.5 to $12.5^{\circ} \mathrm{C}$ (mean is $11.3 \pm 0.15^{\circ} \mathrm{C}, \mathrm{CV}=7.5 \%$, Fig. 1). The temperature dynamics was subject to the linear trend:

$$
\text { Temp }=10.5+0.055 \cdot \mathrm{Y}\left(\mathrm{R}^{2}=0.34, \mathrm{P}<0.001\right)
$$

where Temp is the average annual temperature, $\mathrm{Y}$ - the order of years: 0 $1988,1-1989, \ldots, 30-2018$.

An oscillatory component was also present in the temperature dynamics, which is confirmed by the autocorrelation coefficients with lag 3 $(\mathrm{r}=0.37, \mathrm{P}=0.03)$ and 5 years $(\mathrm{r}=0.48, \mathrm{P}=0.002)$.

The annual rainfall ranged from 220 to $761 \mathrm{~mm}$ (average $-453 \pm$ $23 \mathrm{~mm}, \mathrm{CV}=27.9 \%$ ). There was a linear trend in precipitation dynamics: Prec $=378+5.0 \cdot Y\left(R^{2}=0.13, P=0.04\right)$,

where Prec is the sum of precipitation per year, $\mathrm{Y}$ is the order of years: 0 $1988,1-1989, \ldots, 30-2018$.

It should be noted that the coherent change in precipitation and temperature was observed in the period until 2011. After that, the temperature growth stabilized and the amount of precipitation began to fall sharply. This explains the absence of a statistically significant correlation between temperature and precipitation $(\mathrm{r}=0.25, \mathrm{P}=0.17)$. There was also an oscillatory component in the dynamics of precipitation, which was confirmed by the autocorrelation coefficients with lag $1(\mathrm{r}=0.49, \mathrm{P}=0.004)$ and 4 years $(r=0.29, P=0.009)$. The extent to which the bird communities changed each year relative to the first year of observation, 1988, showed that there were differences between communities in the nature of the dynamics (Fig. 2). For a number of biotopes, turnover measure D is close to zero level, which indicates a quasi-cyclical community dynamic. Such communities included birds from agricultural lands, artificial forest belt, steppe.

Table 2

Species richness of bird communities over the period (1988-2018)

\begin{tabular}{lcccc}
\hline \multicolumn{1}{c}{ Biotope } & $\begin{array}{c}\text { Total for } \\
\text { all periods }\end{array}$ & Minimum & Maximum & Median \\
\hline Agricultural lands & 10 & 5 & 10 & 7 \\
Artificial forest belts & 47 & 40 & 47 & 42 \\
Meadows & 4 & 2 & 4 & 3 \\
Islands and spits & 40 & 7 & 27 & 13 \\
Reed beds & 41 & 7 & 32 & 16 \\
Urban areas & 11 & 8 & 11 & 10 \\
Solonchaks & 13 & 2 & 13 & 10 \\
Steppe & 5 & 2 & 5 & 4 \\
Cliff & 11 & 1 & 9 & 5 \\
Artificial forests & 55 & 52 & 55 & 53 \\
Landscape system as a whole & 132 & 56 & 120 & 95 \\
\hline
\end{tabular}


Two components of the turnover measures provide more detailed information on the causes of community dynamics. D1 quantifies the change in the composition of communities. The change in community abundance is indicated by $\mathrm{D} 2$. When $\mathrm{D} 2$ is positive the community abundance has increased, and when it is negative community abundance has decreased. The decrease in D1 component for these types of ecosystems was compensated by the growth of D2 component. This indicates that the directional change in the structure of the bird community from agricultural lands and artificial forest belts was accompanied by an increase in community size compared to the initial period. For steppe communities, the structure of the bird community was relatively unchanged and the fluctuations were primarily related to its abundance. The structure of the community was also relatively stable with birds from meadows, reed beds, and cliffs. Significant changes in community structure over time were found for birds from islands and spits, and solonchaks. A moderate temporal trend in the community structure was found for artificial forests and urban areas. A moderate trend in community structure was observed for birds from meadows, reed beds, and artificial forests during the survey period. The abundance of bird assemblages from islands and spits and solonchaks was stationary. The abundance of birds from urban areas and cliff showed an increase

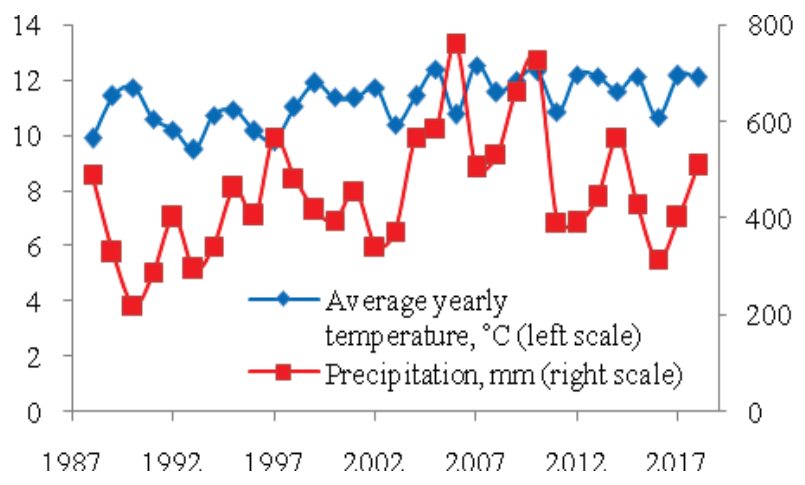

Fig. 1. Dynamics of average annual temperature and annual precipitation: abscissa is a sequence of years, ordinate axis is average yearly temperature, ${ }^{\circ} \mathrm{C}$ (left scale) and precipitation, $\mathrm{mm}$ (right scale)

The species most responsible for the community dynamics in agrarian lands were Alauda arvensis, Corvus monedula, Coturnix coturnix, Melanocorypha calandra, Miliaria calandra (Fig. 3). The role of a species in turnover is indicated by the corresponding area in the figure. Thus, the increasing abundance of Alauda arvensis was accompanied by the increasing role of this species in the community dynamics over time. In its turn, the stable abundance of Corvus monedula in the period near 2000 led to a decrease in the contribution of this species to the community turnover. The species Anas platyrhynchos, Anas strepera, Corvus frugilegus, Egretta garzetta, and Otus scops contributed most to the artificial forest belt community dynamics. The most significant changes in the community structure were due to a dramatic decrease in Anas platyrhynchos and A. strepera populations at the end of the survey period. The constant growth of Corvus frugilegus abundance also resulted in a sharp decline in its abundance starting from 2009. Egretta garzetta and Otus scops were characterized by a decline in abundance throughout the period of research. Motacilla citreola, M. feldegg, M. flava, Saxicola torquatus made the greatest contribution to the turnover of the meadows bird community. The abundance of Motacilla citreola and M. feldegg showed growth until 2010, after which began a monotonous decline in abundance of these species. The abundance of Motacilla flava at different rates decreased throughout the study period. The abundance of Saxicola torquatus was stable until 2012, after which there was a dramatic decrease in the abundance of this species. The largest contributors to the community turnover of islands and spits was contributed by species such as Acrocephalus agricola, Larus cachinnans, Phalacrocorax carbo, Sterna albifrons, S. hirundo. A decrease in the abundance during the whole period of research was found for Acrocephalus agricola. The maximum abundance of Larus cachinnans was recorded in the middle of the research period. An increase in abundance during the research period was found for $P h a-$ lacrocorax carbo. An oscillating dynamic during the research period was revealed for Sterna albifrons and S. hirundo. The greatest contribution to the community turnover of reed beds was made by Acrocephalus arundinaceus, A. scirpaceus, Ardea cinerea, Fulica atra, Gallinula chloropus. The turnover of species in the bird community of urban areas was mainly due to population dynamics of such species as Carduelis carduelis, Galerida cristata, Hirundo rustica, Streptopelia decaocto, Sturnus vulgaris. The largest contribution to the solonchaks' bird community turnover was made by Alauda arvensis, Glareola pratincola, Recurvirostra avosetta, Sterna albifrons, S. hirundo. For S. albifrons and S. hirundo an oscillatory attenuation was found. Alauda arvensis, on the contrary, was characterized by an oscillatory increase in abundance. The same species in the steppe was characterized by oscillatory stationary dynamics. The main contribution to the cliff community turnover was made by such species as Coracias garrulus, Merops apiaster, Passer montanus, Riparia riparia, Tadorna tadorna. The dynamics of the bird community of artificial forests were driven by the population processes of such species as Carduelis cannabina, Fringilla coelebs, Oriolus oriolus, Turdus merula, T. philomelos.

The communities differed in the contribution of various factors to their dynamics (Fig. 4). The role of temperature was greatest for species turnover in communities such as artificial forest belts, artificial forests, and cliff. The role of precipitation was most important for species turnover in meadows bird assemblages. During the research period, the role of precipitation in the dynamics of this community decreased, while the role of temperature and time increased. The role of time factor in species turnover was most important for communities in such habitats as islands and spits, reed beds, urban areas, solonchaks, steepe. For all communities, the role of the time factor was constantly increasing during the research period.

\section{Discussion}

The considered landscape system represents a number of significant environmental gradients, the superposition of which forms a mosaic of the landscape cover of the region. The most important gradient is reflected in the sequence of ecosystems from steppe communities on the plateau to meadow communities in river floodplains, salt marshes and water ecosystems. This gradient is associated with both changes in trophicity and humidity conditions. Artificial forest plantations also bring an important aspect of landscape diversity. As a rule, such ecosystems are on the plateau. Agro-ecosystems are an example of a significant transformation of steppe ecosystems (Oparin \& Oparina, 2012). Urban ecosystems are also subjected to the anthropogenic impact (Alberti, 2005). Forest ecosystems are island in nature because they are completely surrounded by either steppe or agro-ecosystems. Islands and spits are more consistent with the traditional view of island ecosystems. In general, the island nature and the high degree of contact with typologically different ecosystems is a characteristic feature of almost all ecosystems in the region. Significant typological features of ecosystems create the conditions for formation of peculiar bird communities, but there is a high level of mutual influence and reciprocal resistance between the different ecosystems. The types of land use in surrounding matrices have an influence on bird communities (Pereira et al., 2014). We can suggest that bird assemblages may not only have specific features in their species composition, but also differ in the features of time dynamics and the nature of response to environmental factors.

Three sources of variation in bird assemblages were considered in our study: average annual temperature, sum of the annual precipitation, and time factor. The average annual temperature is a complex indicator that characterizes both the total amount of heat received by a given area and is indirectly related to the course of temperatures during the year (Srinivasan et al., 2019). Rhythmic thermal processes affect the phenology of both plants and animals, which act as trophic resources for birds (Gordo \& Sanz, 2006; Renner et al., 2012; McDermott \& DeGroote, 2016; Chaplygina et al., 2018, 2019; Haest et al., 2019; Zhukov et al., 2019). The latter circumstance is especially important for the feeding of birds during the breeding season (Visser et al., 2012; Halupka \& Halupka, 2017; Shutt et al., 2019). The state of the plant cover determines the trophic resources of birds (Mäntylä et al., 2011; Albrecht et al., 2018; Zhang et al., 2018). Also, plants play an important role as factors that determine the physiognomy of the ecological space of birds. Thermal regime of the territory affects the intensity of evaporation processes from both the land surface 
and the surface of aquatic ecosystems (Caissie, 2006). The rate of evaporation of meadow and saline ecosystems affects the level of their salinization (Vengosh, 2003; Li et al., 2007). The salinity of the Molochny estuary also strongly depends on the intensity of evaporation from the water surface. In a shallow water body such as the Molochny estuary, evaporation is an important part of the water balance.

In the steppe zone, the moisture is the most important environmental factor, which determines the dynamics of ecological processes (Shvidenko et al., 2017; Török et al., 2020). This factor by the nature of its impact is the opposite of the temperature regime. Precipitation compensates for moisture that is lost in the process of evaporation and also helps to reduce salinity of soil or aquatic ecosystems. The total amount of precipitation per year is also associated with the rhythm of precipitation during the year. As a rule, the growth of precipitation is increased by rains, which have a stormy character (Vandandorj et al., 2017). Intensive rainfall leads to increased erosion processes and increased surface run off and the inflow of sediment into water bodies (Meddi, 2013). The results indicate that tem-
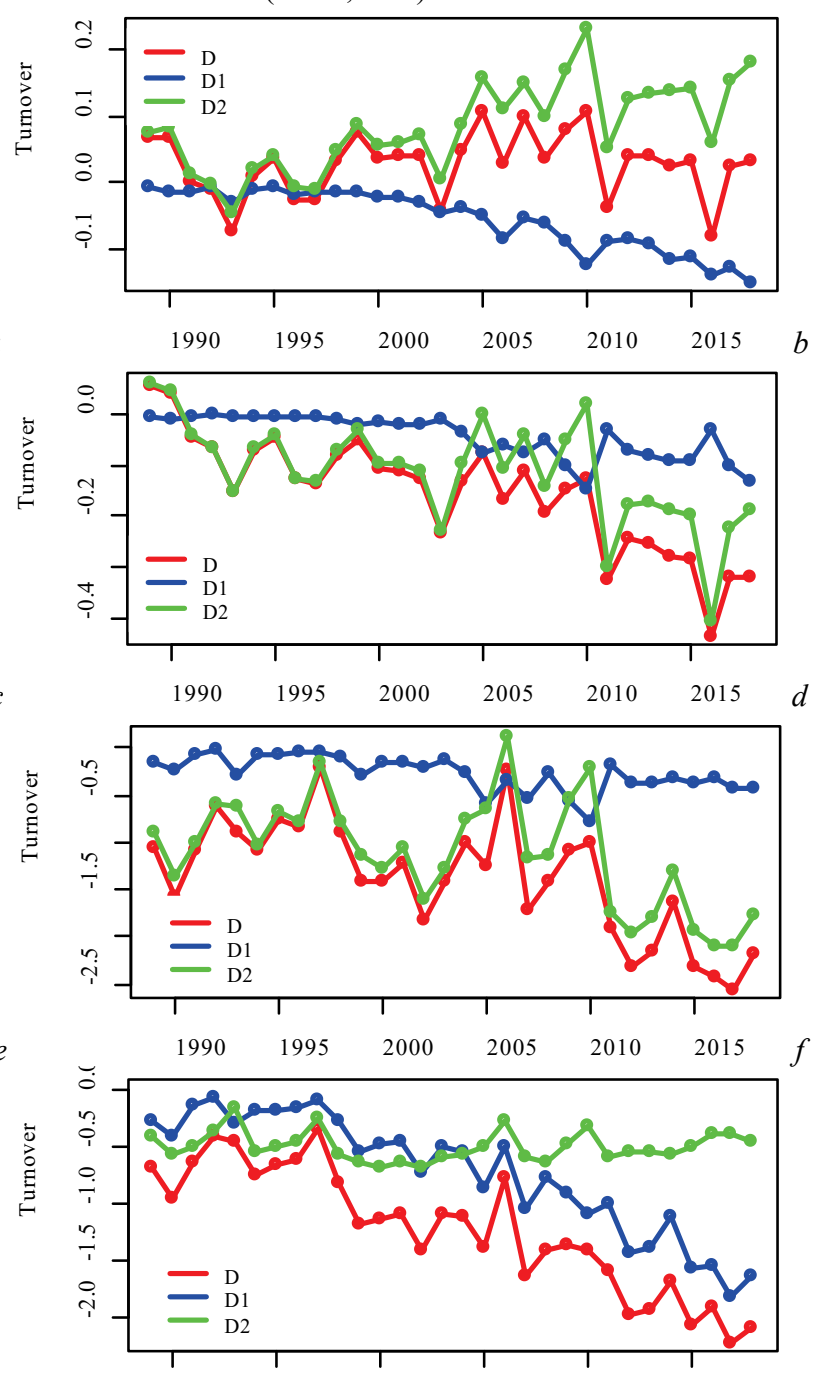

$g$

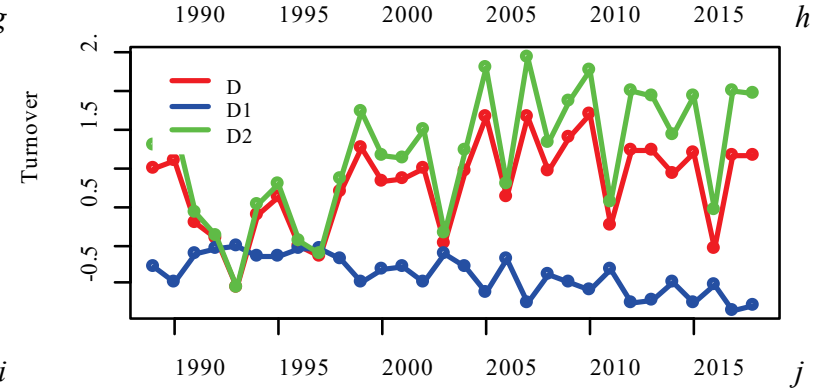

perature and precipitation dynamics have their specific features, so these factors should be considered as independent. The role of the time factor is the most difficult to interpret. Formally, this factor manifests itself in the presence of a linear trend, which is valid for the entire period studied. It is tempting to accept this trend as one that is due to global climate change. Obviously, this assumption is not without common sense and can be considered as one of the possible alternatives. However, it is impossible to reject explanations which are based not only on the action of external causes, but also on the action of internal nature. The action of the so-called time factor can be related to the presence of such a property of the system as memory. Endogenous processes can be started and developed over a long period of time, forming a mutually dependent sequence of states of the system. Thus, both external and internal nature factors can be used as alternative explanations of the temporal trend occurrence. It is also impossible to exclude the complex nature of the time trend as a result of the action of both external and internal nature factors on the bird communities.

\section{离}

$b$
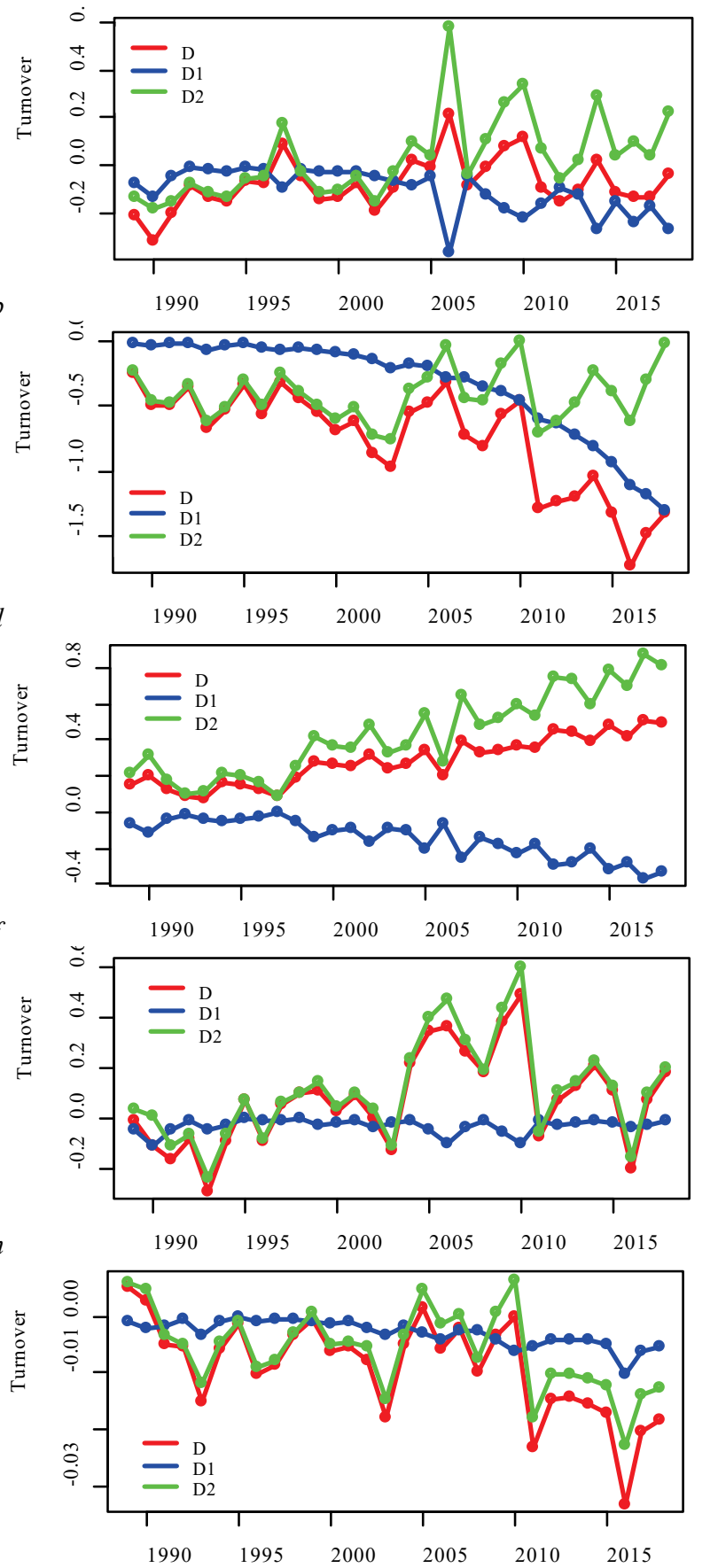

Fig. 2. The turnover measure (D: the red line) and its components, the composition change (D1: the blue line) and the community size change (D2: the green line) obtained after the turnover analysis on the bird communities at Molochniy estuary over the period (1988-2018): 
abscissa axis is the order of years, ordinate axis is the turnover; $a$-agricultural lands; $b$-artificial forest belt; $c$-meadows; $d$-islands and spits; $e$-reed beds; $f$ - urban areas; $g$ - solonchaks; $h$ - steppe; $i$ - cliff; $j$-artificial forests

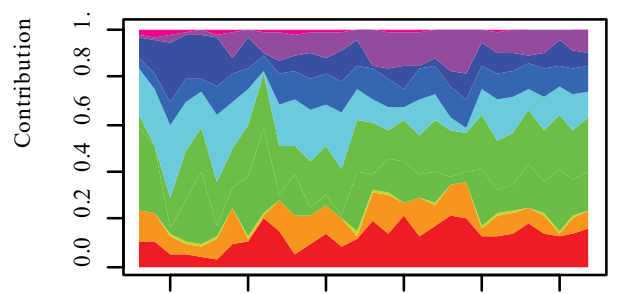

$a$

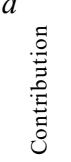

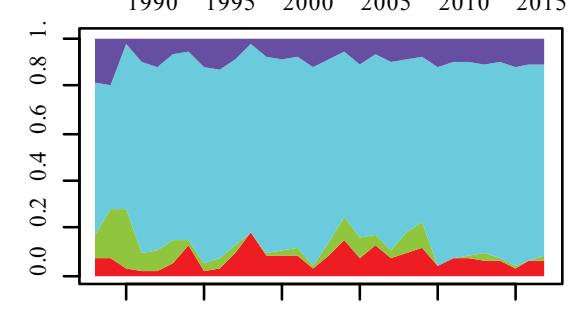

$c$
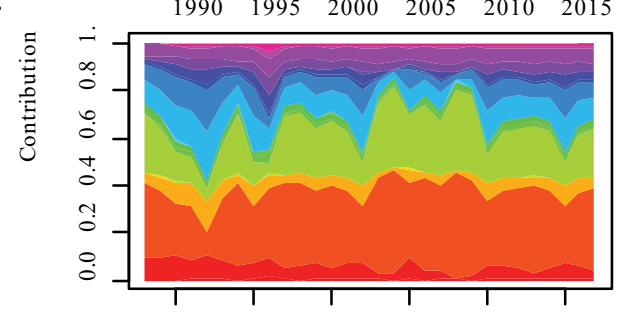

$e$

$$
\text { e. }
$$

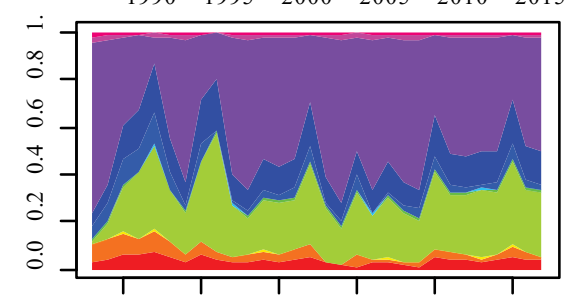

$g$

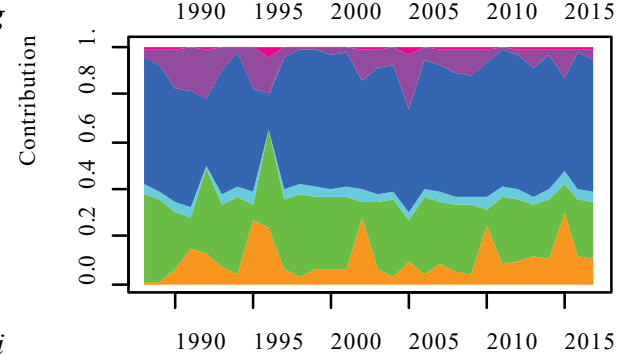

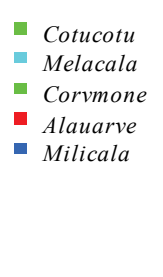

$b$
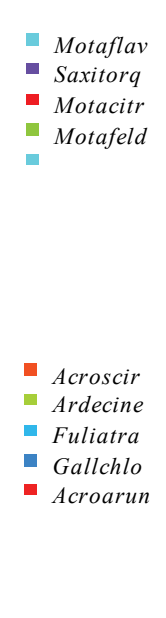

$f$

- Sterhiru

- Steralbi

- Recuavos

- Alauarve

Alauarve

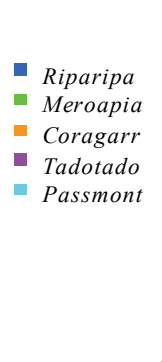

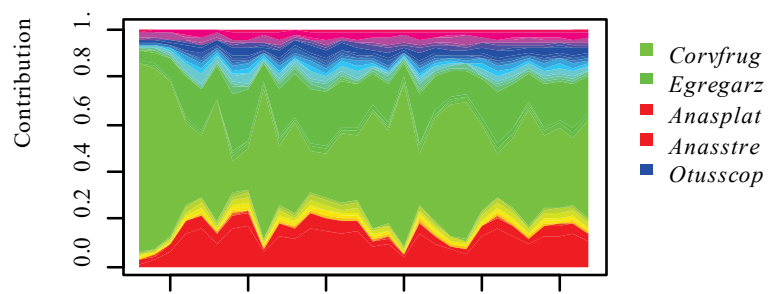

b $\quad 1990 \quad 1995 \quad 2000 \quad 2005 \quad 2010 \quad 2015$

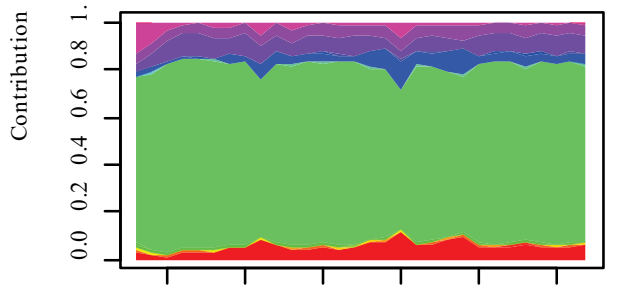

d $\quad \begin{array}{llllll}1990 & 1995 & 2000 & 2005 & 2010 & 2015\end{array}$

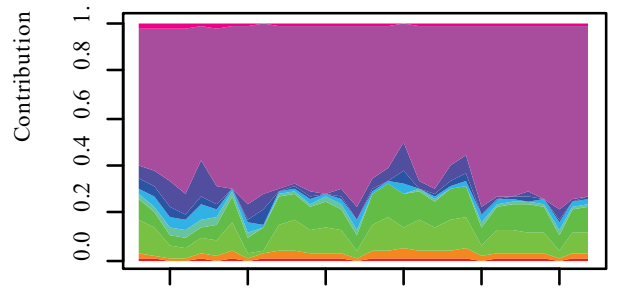

f $\quad \begin{array}{llllll}1990 & 1995 & 2000 & 2005 & 2010 & 2015\end{array}$

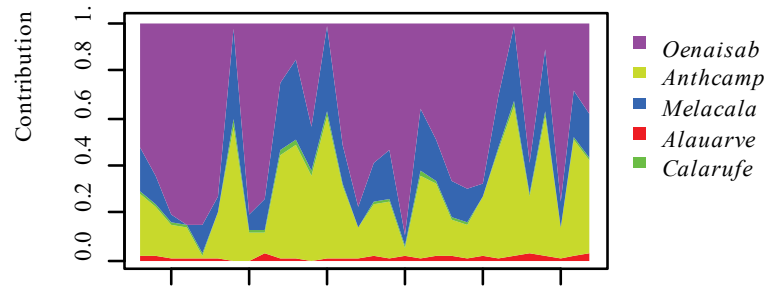

$h$

$\begin{array}{llllll}1990 & 1995 & 2000 & 2005 & 2010 & 2015\end{array}$

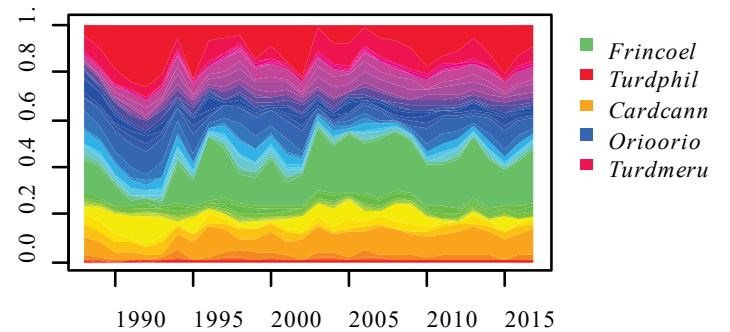

Fig. 3. The contribution ratios of each species in the community obtained after the turnover analysis on the bird communities at Molochniy estuary over the period (1988-2018): top five species with high contribution ratio are listed in the legend, and other colour/shading represent(s) the remaining species: abscissa axis is the order of years, ordinate axis is the contribution ratio: $a$-agricultural lands: Alauarve - Alauda arvensis; Corvmone - Corvus monedula; Cotucotu-Coturnix coturnix; Melacala-Melanocorypha calandra; Milicala-Miliaria calandra; $b$-artificial forest belt: Anasplat - Anas platyrhynchos; Anasstre-Anas strepera; Corvfrug - Corvus frugilegus; Egregarz - Egretta garzetta; Otusscop - Otus scops; c-meadows: Motacitr - Motacilla citreola, Motafeld - M. feldegg, Motaflav-M.flava, Saxitorq-Saxicola torquatus; $d$-islands and spits: Acroagri-Acrocephalus agricola, LarucachLarus cachinnans, Phalcarb - Phalacrocorax carbo, Steralbi - Sterna albifrons, Sterhiru - S. hirundo, e-reed beds: Acroarun - Acrocephalus arundinaceus, Acroscir-A. scirpaceus, Ardecine - Ardea cinerea, Fuliatra - Fulica atra, Gallchlo-Gallinula chloropus; $f$ - urban areas: Cardcard-Carduelis carduelis, Galecris - Galerida cristata, Hirurust - Hirundo rustica, Stredeca - Streptopelia decaocto, Sturvulg - Sturnus vulgaris; $g$-solonchaks:

Alauarve - Alauda arvensis, Glarprat-Glareola pratincola, Recuavos - Recurvirostra avosetta, Steralbi - Sterna albifrons, Sterhiru-S. hirundo; $h$-Steppe: Alauarve - Alauda arvensis, Anthcamp - Anthus campestris, Calarufe - Calandrella rufescens, Melacala - Melanocorypha calandra, Oenaisab-Oenanthe isabellina; $i$-cliff: Coragarr-Coracias garrulus, Meroapia-Merops apiaster, Passmont-Passer montanus, Riparipa-Riparia riparia, Tadotado - Tadorna tadorna; $j$ - artificial forests: Cardcann - Carduelis cannabina, Frincoel - Fringilla coelebs, Orioorio - Oriolus oriolus, Turdmeru Turdus merula, Turdphil-T. philomelos

The steppe bird community was represented by an extremely small number of species, but demonstrated the ability to maintain a stable structure for a long time. The main fluctuations of the community were quantitative changes in abundance, while the turnover of species was practically absent. Species of the community replace each other cyclically, but there were no targeted changes in community structure. Temperature and precipitation were the main drivers of the bird community in the steppe. The role of the time factor was extremely insignificant. Thus, variation in the abundance of species in a bird assemblage made it possible to maintain a stable structure under changing environmental conditions with extremely low species diversity of the community. In wetter meadows, a community was formed that consisted of a few more species than in the steppe. 
The turnover of species was insignificant, but higher than in the steppe. The main changes in community were associated with a decrease in community abundance, which was the most dramatic in the last survey period.

A sharp decrease in the abundance of the bird assemblage in meadows occurred when the increase in temperature was no longer compensated by increased precipitation. It should be noted that the main driver of bird community dynamics in the meadows was the time factor. The dynamics launched during the initial period of the research continued to develop throughout the time range. The role of community species remained practically unchanged. All species were characterized by a decrease in abundance throughout the entire research period. Meadow habitats are located in the upper part of the estuary. Small lakes are located in the meadow communities. The meadow complex of species has been monotonically degraded during the whole period of research. The bird communities on salt marshes were characterized by a stable abundance, but a constant directed turnover of species. This species complex continues the trend of increasing species richness in the sequence of steppe $\rightarrow$ meadow $\rightarrow$ salt marshes. The turnover of species was mainly due to a decrease in the
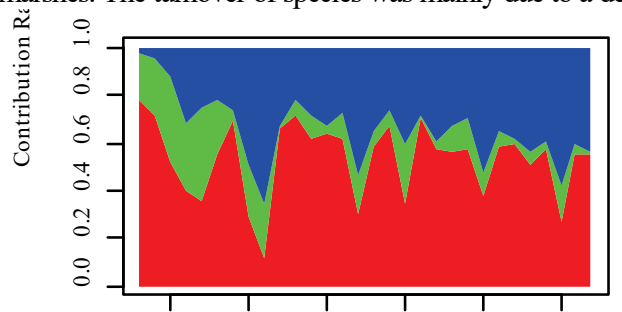

- Temperature

- Time

- Precipitation

$a$

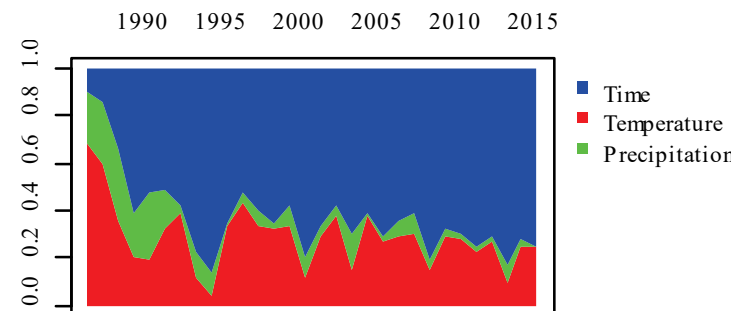

c

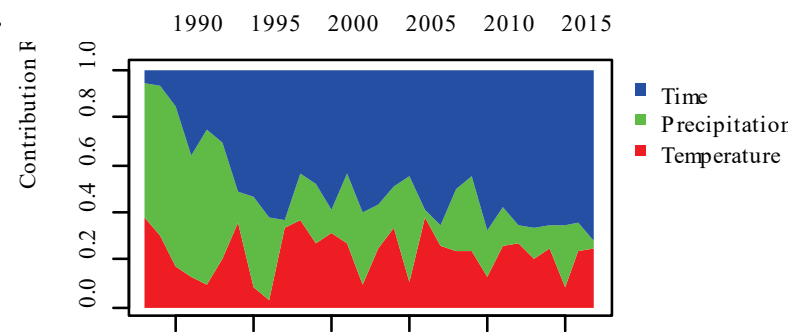

$e$

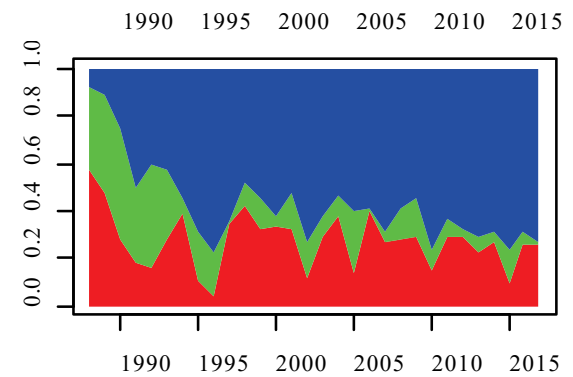

$g$

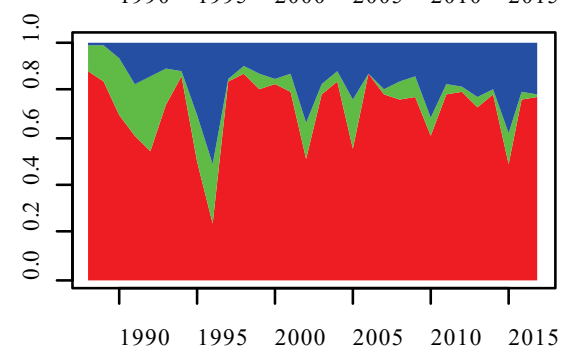

- Time

- Temperature

- Precipitation abundance of Glareola pratincola and Sterna hirundo. Reduced water levels and the disappearance of islands in the salt marshes increased the risk of threats from predators, which could lead to a decrease in the abundance of these species. This explains the increasing time factor in community dynamics as temperature and precipitation diminish. The monotonous decrease in the level of the Molochny estuary was the cause of drying up the saline systems and increasing the level of connectivity of its individual fragments. Such dynamics was observed for reed bed bird communities. This type of habitat was characterized by even higher humidity and a much higher level of species richness than the previously considered ecosystems. The turnover of species was extremely low and the dynamics of the community primarily manifested itself in changes in abundance. A particularly sharp decline in abundance was observed in the last period of the survey - after 2010. The role of the temperature factor remained practically unchanged throughout the period of research. Precipitation was the dominant factor at the initial stage of the survey, but then its role gave way to the time factor. The most important species that determined the dynamics of the community structure was Ardea cinerea.
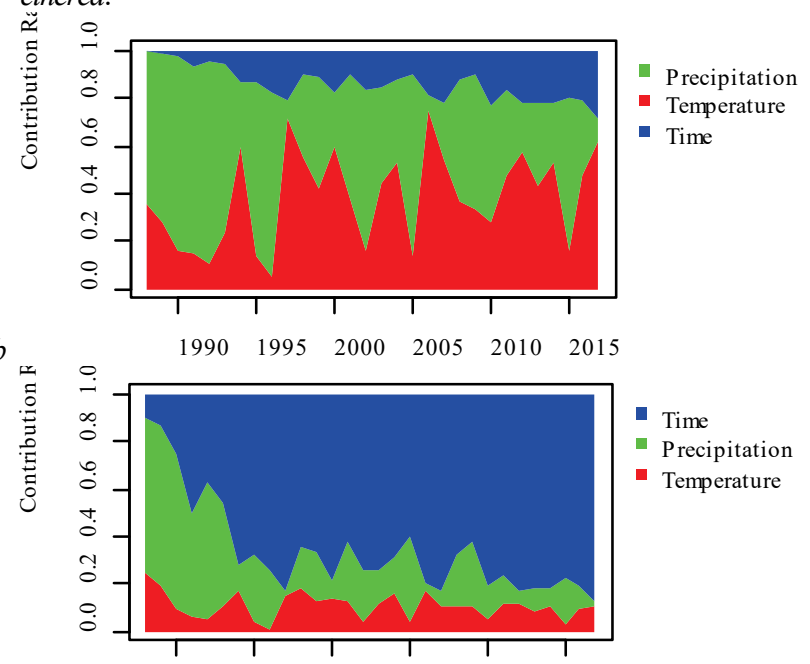

$d$

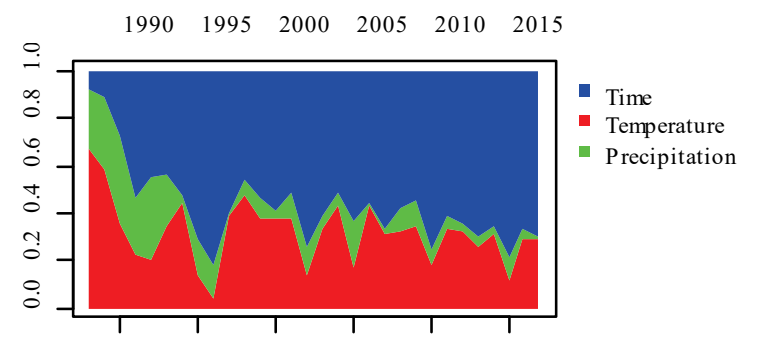

$f$

ن

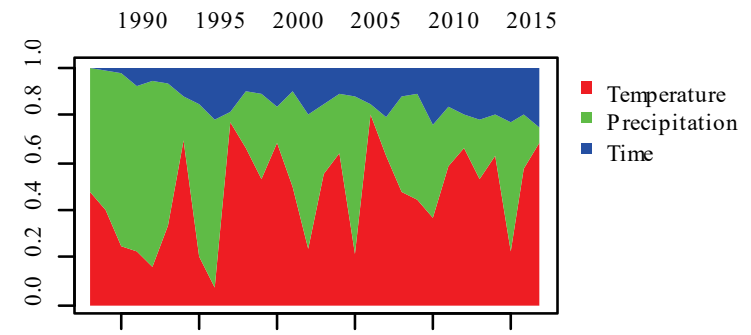

$h$

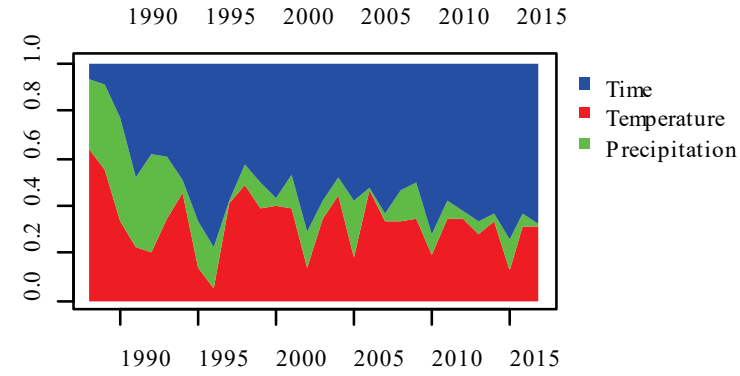


Fig. 4. The contribution ratios of each environmental factor estimated after the turnover analysis of the bird communities at the Molochniy estuary over the period (1988-2018): ordinate axis is the contribution ratio; year (blue), precipitation (green) and temperature (red); $a$-agricultural lands; $b$-artificial forest belt; $c$-meadows; $d$-islands and spits; $e$-reed beds; $f$ - urban areas; $g$-solonchaks; $h$-steepe; $i$-cliff; $j$-artificial forests

This is logical because nests of this species formed biodiversity hotspots in the homogeneous plant communities of reed beds. It is known that the availability of nesting sites is the most important driver of bird community diversity (Kennedy et al., 2010). Deterioration of hydrological conditions led to a decrease in the number of Ardea cinerea, which in turn led to a decrease in all species of the community without significant turnover. Habitat change at the landscape level affects the distribution and abundance of organisms (Taylor \& Lindenmayer, 2020) and, for specialized species, habitat reduction and fragmentation can disrupt key biological processes such as reproduction, dispersion and resource development (Saunders et al., 1991; Blandón et al., 2016).

Almost the same species richness as in the reed beds was characterized by bird assemblages of islands and spits. These communities were characterized by high species turnover with quasi-cyclical population dynamics. The main feature of the community dynamics was a decrease in the role of precipitation and an increase in the role of the time factor. The role of temperature remained stably low. Larus cachinnans was the most important species that provided the turnover of the community. Since 2000, there was a sharp decline in the population of this species. The main factor of community dynamics on the islands was their contact with the mainland as a result of decrease in the water level of the estuary. The islands ceased to have a protective function and the bird population decreased dramatically.

In addition to the natural gradient, which is defined by the variability of humidity conditions, within the studied landscape system there is a gradient due to anthropogenic influence. It should be noted that the species richness of bird communities in agrarian lands was higher than in steppe communities. This result confirms the evidence that in some cases agricultural land can support a high level of biodiversity (Karp et al., 2012, 2018). The turnover measure was stationary. It should be noted that the land cover changes in the agricultural landscape may have a little impact on the temporary beta diversity of bird communities (Baselga et al., 2015). The turnover measure was significant because of the increased abundance of Alauda arvensis. Over time, the role of precipitation in the community dynamics has been decreasing and the role of time has been increasing. The value of temperature varied, but was at a stationary level. The turnover of species was compensated by an increase in the abundance of bird communities. The increase in abundance can be attributed to the growth of the forage base, which increased with the growth of crop yields, which was observed since the second half of the 1990s (Zymaroieva et al., 2019, 2020).

Artificial forest strips and plantations were notable for their considerable species richness. The spread of forests in Mediterranean regions led to a shift in bird communities in favor of forest species (Sirami et al., 2006; Giltena et al., 2009). The main aspect of community dynamics was the variation in numbers with a low level of species turnover. Forest plantations in the steppe exist in highly extreme conditions in the steppe, which is due to the significant variability of bird life conditions in them. Contamination, felling, fires and the disturbance factor are the reasons for sharp fluctuations in the bird population in artificial plantations (Spake et al., 2020). The precipitation factor was the leading one for forming the dynamics of bird communities in forest strips. The time factor was important for the artificial forest plantations. Urban bird communities were characterized by a constant turnover of species and growth of communities. Highly urbanized territories allow bird communities to have a more stable composition over time, contributing to temporal homogenization. Urbanization changes the temporal dynamics of resources and, consequently, the temporal variability of bird communities (Leveau et al., 2015). At the initial stages of the research, the temperature factor played the leading role in the community dynamics. Then, the advantage passed to the time factor. The leading species that determines community turnover was Sturnus vulgaris.

A number of studies have concluded that climate change has overtaken the intensity of land use as a driver of population dynamics in ordinary European birds (Moller et al., 2008; Gregory et al., 2009; Davey et al.,
2010). However, our results are in line with findings indicating that despite more stable land use intensities in recent years, climate change has not overtaken land use intensities as the main driver of bird population dynamics (Eglington \& Pearce-Higgins, 2012; Renner \& Bates, 2020).

\section{Conclusion}

The dynamics of the bird metacommunity in a diverse landscape system over the past 30 years occurred in the context of global climate change. These changes affected the temperature and precipitation patterns and the role of these processes is undoubtedly important. However, the real dynamics of bird communities are mainly due to local environmental processes, many of which are induced by anthropogenic factors. A negative human impact on ecosystems has significant temporal consequences, which are imposed on global trends. This circumstance significantly complicates the differential assessment of the role of global and local factors. One should also note the role of endogenous factors, which also initiate the dynamics of bird communities. Obvious practical recommendations are to develop strategies aimed at minimizing local negative effects of anthropogenic influence and maintaining landscape diversity as a factor of sustainability of ecological communities.

\section{References}

Alberti, M. (2005). The effects of urban patterns on ecosystem function. International Regional Science Review, 28(2), 168-192.

Albrecht, J., Classen, A., Vollstädt, M. G. R., Mayr, A., Mollel, N. P., Schellenberger Costa, D., Dulle, H. I., Fischer, M., Hemp, A., Howell, K. M., Kleyer, M., Nauss, T., Peters, M. K., Tschapka, M., Steffan-Dewenter, I., Böhning-Gaese, K., \& Schleuning, M. (2018). Plant and animal functional diversity drive mutualistic network assembly across an elevational gradient. Nature Communications, 9(1), 3177

Anderson, M. J., Crist, T. O., Chase, J. M., Vellend, M., Inouye, B. D., Freestone, A. L., Sanders, N. J., Comell, H. V., Comita, L. S., Davies, K. F., Harrison, S. P., Kraft, N. J. B., Stegen, J. C., \& Swenson, N. G. (2011). Navigating the multiple meanings of $\beta$ diversity: A roadmap for the practicing ecologist. Ecology Letters, 14(1), 19-28.

Angeler, D. G., Viedma, O., \& Moreno, J. M. (2009). Statistical performance and information content of time lag analysis and redundancy analysis in time series modeling. Ecology, 90(11), 3245-3257.

Azeria, E. T., Carlson, A., Pärt, T., \& Wiklund, C. G. (2006). Temporal dynamics and nestedness of an oceanic island bird fauna. Global Ecology and Biogeography, 15(4), 328-338.

Barbe, L., Morel, R., Rantier, Y., Lebas, J.-F., \& Butet, A. (2018). Bird communities of a temperate forest: Spatio-temporal partitioning between resident and migratory species. Journal of Omithology, 159(2), 457-469.

Baselga, A., Bonthoux, S., \& Balent, G. (2015). Temporal beta diversity of bird assemblages in agricultural landscapes: Land cover change vs. stochastic processes. PLoS One, 10(5), e0127913.

Blandón, A. C., Perelman, S. B., Ramírez, M., López, A., Javier, O., \& Robbins, C.S. (2016). Temporal bird community dynamics are strongly affected by landscape fragmentation in a Central American tropical forest region. Biodiversity and Conservation, 25(2), 311-330.

Bradbury, R. B., Hill, R. A., Mason, D. C., Hinsley, S. A., Wilson, J. D., Balzter, H., Anderson, G. Q. A., Whittingham, M. J., Davenport, I. J., \& Bellamy, P. E. (2005). Modelling relationships between birds and vegetation structure using airborne LiDAR data: A review with case studies from agricultural and woodland environments. Ibis, 147(3), 443-452.

Bray, J. R., \& Curtis, J. T. (1957). An ordination of the upland forest communities of southern Wisconsin. Ecological Monographs, 27(4), 325-349.

Brown, B. L., \& Lawson, R. L. (2010). Habitat heterogeneity and activity of an omnivorous ecosystem engineer control stream community dynamics. Ecology, 91(6), 1799-1810.

Caissie, D. (2006). The thermal regime of rivers: a review. Freshwater Biology, 51(8), 1389-1406.

Carpenter, S. R., \& Brock, W. A. (2006). Rising variance: A leading indicator of ecological transition. Ecology Letters, 9(3), 311-318.

Chalcraft, D. R., Williams, J. W., Smith, M. D., \& Willig, M. R. (2004). Scale dependence in the species-richness - productivity relationship: The role of species turnover. Ecology, 85(10), 2701-2708.

Chamberlain, D. E., Fuller, R. J., Bunce, R. G. H., Duckworth, J. C., \& Shrubb, M. (2000). Changes in the abundance of farmland birds in relation to the timing of 
agricultural intensification in England and Wales. Journal of Applied Ecology, 37(5), 771-788.

Chaplygina, A. B., Savynska, N. O., \& Brygadyrenko, V. V. (2018). Trophic links of the spotted flycatcher, Muscicapa striata, in transformed forest ecosystems of North-Eastern Ukraine. Baltic Forestry, 24(2), 304-312.

Chaplygina, A. B., Pakhomov, O. Y., \& Brygadyrenko, V. V. (2019). Trophic links of the song thrush (Turdus philomelos) in transformed forest ecosystems of North-Eastem Ukraine. Biosystems Diversity, 27(1), 51-55.

Coelho, M. T. P., Dambros, C., Rosauer, D. F., Pereira, E. B., \& Rangel, T. F. (2019). Effects of neutrality and productivity on mammal richness and evolutionary history in Australia. Ecography, 42(3), 478-487.

Connell, J. H., \& Slatyer, R. O. (1977). Mechanisms of succession in natural communities and their role in community stability and organization. The American Naturalist, 111(982), 1119-1144.

Cramer, M. J., \& Willig, M. R. (2005). Habitat heterogeneity, species diversity and null models. Oikos, 108(2), 209-218.

Davey, C. M., Vickery, J. A., Boatman, N. D., Chamberlain, D. E., Parry, H. R., \& Siriwardena, G. M. (2010). Assessing the impact of entry level stewardship on lowland farmland birds in England. Ibis, 152(3), 459-474.

Doak, D. F., Bigger, D., Harding, E. K., Marvier, M. A., O’Malley, R. E., \& Thomson, D. (1998). The statistical inevitability of stability-diversity relationships in community ecology. American Naturalist, 151(3), $264-276$.

Donald, P. F., Green, R. E., \& Heath, M. F. (2001). Agricultural intensification and the collapse of Europe's farmland bird populations. Proceedings of the Royal Society B: Biological Sciences, 268(1462), 25-29.

Dornelas, M., Magurran, A. E., Buckland, S. T., Chao, A., Chazdon, R. L., Colwell, R. K., Curtis, T., Gaston, K. J., Gotelli, N. J., Kosnik, M. A., McGill, B. McCune, J. L., Morlon, H., Mumby, P. J., Øvreås, L., Studeny, A., \& Vellend, M. (2013). Quantifying temporal change in biodiversity: Challenges and opportunities. Proceedings of the Royal Society B: Biological Sciences, 280(1750), 20121931.

Durant, J. M., Skern-Mauritzen, M., Krasnov, Y. V., Nikolaeva, N. G., Lindstrøm, U., \& Dolgov, A. (2014). Temporal dynamics of top predators interactions in the Barents sea. PLoS One, 9(11), el10933.

Eglington, S. M., \& Pearce-Higgins, J. W. (2012). Disentangling the relative importance of changes in climate and land-use intensity in driving recent bird population trends. PLoS One, 7(3), e30407.

Fischer, J., \& Lindenmayer, D. B. (2007). Landscape modification and habitat fragmentation: A synthesis. Global Ecology and Biogeography, 16(3), 265-280.

Flynn, D. F. B., Gogol-Prokurat, M., Nogeire, T., Molinari, N., Richers, B. T., Lin, B. B., Simpson, N., Mayfield, M. M., \& DeClerck, F. (2009). Loss of functional diversity under land use intensification across multiple taxa. Ecology Letters, $12(1), 22-33$

Gil-tena, A., Brotons, I., \& Saura, S. (2009). Mediterranean forest dynamics and forest bird distribution changes in the late 20th century. Global Change Biology, 15(2), 474485

Goetz, S. J., Steinberg, D., Betts, M. G., Holmes, R. T., Doran, P. J., Dubayah, R., \& Hofton, M. (2010). Lidar remote sensing variables predict breeding habitat of a Neotropical migrant bird. Ecology, 91(6), 1569-1576

Gonzalez, A., \& Descamps-Julien, B. (2004). Population and community variability in randomly fluctuating environments. Oikos, 106(1), 105-116.

Gordo, O., \& Sanz, J. J. (2006). Climate change and bird phenology: A long-term study in the Iberian Peninsula. Global Change Biology, 12(10), 1993-2004.

Gotelli, N. J., \& Ulrich, W. (2012). Statistical challenges in null model analysis. Oikos, 121(2), 171-180.

Gregory, R. D., Noble, B. G., \& Custance, J. (2004). The state of play of farmland birds: population trends and conservation status of lowland farmland birds in the United Kingdom. Ibis, 146, 1-13.

Gregory, R. D., Willis, S. G., Jiguet, F., Voříšek, P., Klvaňová, A., van Strien, A. Huntley, B., Collingham, Y. C., Couvet, D., \& Green, R. E. (2009). An indicator of the impact of climatic change on European bird populations. PLoS One, 4(3), e4678.

Haest, B., Hüppop, O., Pol, M., \& Bairlein, F. (2019). Autumn bird migration phenology: A potpourri of wind, precipitation and temperature effects. Global Change Biology, 25(12), 40644080.

Halupka, L., \& Halupka, K. (2017). The effect of climate change on the duration of avian breeding seasons: A meta-analysis. Proceedings of the Royal Society B: Biological Sciences, 284(1867), 1710.

Hanski, I. (1998). Metapopulation dynamics. Nature, 396(6706), 41-49.

Hillebrand, H., Soininen, J., \& Snoeijs, P. (2010). Warming leads to higher species turnover in a coastal ecosystem. Global Change Biology, 16(4), 1181-1193.

Houlahan, J. E., Currie, D. J., Cottenie, K., Cumming, G. S., Ernest, S. K. M., Findlay, C. S., Fuhlendorf, S. D., Gaedke, U., Legendre, P., Magnuson, J. J., McArdle, B. H., Muldavin, E. H., Noble, D., Russell, R., Stevens, R. D., Willis, T. J., Woiwod, I. P., \& Wondzell, S. M. (2007). Compensatory dynamics are rare in natural ecological communities. Proceedings of the National Academy of Sciences of the United States of America, 104(9), 3273-3277.
Hubbell, S. P. (2005). Neutral theory in community ecology and the hypothesis of functional equivalence. Functional Ecology, 19(1), 166-172.

Hutchinson, G. E. (1957). Concluding remarks. Cold Spring Harbor Symposia on Quantitative Biology, 22, 415-427.

Hutchinson, G. E. (1965). The niche: An abstractly inhabited hypervolume. The ecological theatre and the evolutionary play. Yale University Press, New Haven.

Jiguet, F., Devictor, V., Ottvall, R., Van Turnhout, C., Van der Jeugd, H., \& Lindström, A. (2010). Bird population trends are linearly affected by climate change along species thermal ranges. Proceedings of the Royal Society B: Biological Sciences, 277(1700), 3601-3608.

Jiguet, F., Gadot, A.-S., Julliard, R., Newson, S., \& Couvet, D. (2007). Climate envelope, life history traits and the resilience of birds facing global change. Global Change Biology, 13(8), 1672-1684.

Kampichler, C, Angeler, D. G., Holmes, R. T, Leito, A, Svensson, S, van der Jeugd, H. P., \& Wesołowski, T. (2014). Temporal dynamics of bird community composition: An analysis of baseline conditions from long-term data. Oecologia, 175(4), 1301-1313.

Karp, D. S., Frishkoff, L. O., Echeverri, A., Zook, J., Juárez, P., \& Chan, K. M. A (2018). Agriculture erases climate-driven $\beta$-diversity in Neotropical bird communities. Global Change Biology, 24(1), 338-349.

Karp, D. S., Rominger, A. J., Zook, J., Ranganathan, J., Ehrlich, P. R., \& Daily, G. C. (2012). Intensive agriculture erodes $\beta$-diversity at large scales. Ecology Letters, 15(9), 963-970

Kennedy, C. M., Marra, P. P., Fagan, W. F., \& Neel, M. C. (2010). Landscape matrix and species traits mediate responses of Neotropical resident birds to forest fragmentation in Jamaica. Ecological Monographs, 80(4), 651-669.

La Sorte, F. A., \& Boecklen, W. J. (2005). Temporal turnover of common species in avian assemblages in North America. Journal of Biogeography, 32(7), $1151-1160$.

Laliberte, E., Wells, J. A., DeClerck, F., Metcalfe, D. J., Catterall, C. P., Queiroz, C., Aubin, I., Bonser, S. P., Ding, Y., Fraterrigo, J. M., McNamara, S., Morgan, J. W., Merlos, D. S., Vesk, P. A., \& Mayfield, M. M. (2010). Land-use intensification reduces functional redundancy and response diversity in plant communities. Ecology Letters, 13(1), 76-86.

Legendre, P., \& Gauthier, O. (2014). Statistical methods for temporal and space-time analysis of community composition data. Proceedings of the Royal Society B Biological Sciences, 281(1778), 2728.

Lehman, C. L., \& Tilman, D. (2000). Biodiversity, stability, and productivity in competitive communities. American Naturalist, 156(5), 534-552.

Leveau, L. M., Isla, F. I., \& Bellocq, M. I. (2015). Urbanization and the temporal homogenization of bird communities: A case study in central Argentina. Urban Ecosystems, 18(4), 1461-1476.

Lewthwaite, J. M. M., Debinski, D. M., \& Kerr, J. T. (2017). High community turnover and dispersal limitation relative to rapid climate change. Global Ecology and Biogeography, 26(4), 459-471.

Li, S.-G., Asanuma, J., Kotani, A., Davaa, G., \& Oyunbaatar, D. (2007). Evapotranspiration from a Mongolian steppe under grazing and its environmental constraints. Journal of Hydrology, 333(1), 133-143.

Loreau, M. (2010). Linking biodiversity and ecosystems: Towards a unifying ecological theory. Philosophical Transactions of the Royal Society B: Biological Sciences, 365(1537), 49-60.

Lyons, M. B., Roelfsema, C. M., \& Phinn, S. R. (2013). Towards understanding temporal and spatial dynamics of seagrass landscapes using time-series remote sensing. Estuarine, Coastal and Shelf Science, 120, 42-53.

Mäntylä, E., Klemola, T., \& Laaksonen, T. (2011). Birds help plants: A metaanalysis of top-down trophic cascades caused by avian predators. Oecologia $165(1), 143-151$

Marini, G., Guzzetta, G., Baldacchino, F., Arnoldi, D., Montarsi, F., Capelli, G., Rizzoli, A., Merler, S., \& Rosà, R. (2017). The effect of interspecific competition on the temporal dynamics of Aedes albopictus and Culex pipiens. Parasites and Vectors, 10(1), 102

Márquez-Luna, U., Lara, C., Corcuera, P., \& Valverde, P. L. (2019). Factors affecting the dominance hierarchy dynamics in a hummingbird assemblage. Current Zoology, 65(3), 261-268

McCullagh, P., \& Nelder, J. (1989). Generalized linear models (2nd ed.). Chapman and Hall/CRC, Boca Raton, London, New York, Washington.

McDermott, M. E., \& DeGroote, L. W. (2016). Long-term climate impacts on breeding bird phenology in Pennsylvania, USA. Global Change Biology, 22(10), $3304-3319$.

Meddi, M. (2013). Sediment transport and rainfall erosivity evolution in twelve basins in Central and Western Algeria. Joumal of Urban and Environmental Engineering, 2013, 253-263.

Moller, A. P., Rubolini, D., \& Lehikoinen, E. (2008). Populations of migratory bird species that did not show a phenological response to climate change are declining. Proceedings of the National Academy of Sciences, 105(42), 16195 16200.

Moraitis, M. L., \& Karakassis, I. (2020). Assessing large-scale macrobenthic community shifts in the Aegean Sea using novel beta diversity modelling methods. 
Ramifications on environmental assessment. Science of The Total Environment, 734, 139504.

Oparin, M. L., \& Oparina, O. S. (2012). Transformation of bird and mammal faunas in steppe ecosystems under the impact of plowing: The example of Saratov steppes. Biology Bulletin, 39(10), 816-822.

Parmesan, C., \& Yohe, G. (2003). A globally coherent fingerprint of climate change impacts across natural systems. Nature, 421(6918), 37-42.

Pereira, P., Godinho, C., Gomes, M., \& Rabaça, J. E. (2014). The importance of the surroundings: Are bird communities of riparian galleries influenced by agroforestry matrices in SW Iberian Peninsula? Annals of Forest Science, 71(1), 33-41.

Renner, S. C., \& Bates, P. J. J. (2020). Historic changes in species composition for a globally unique bird community. Scientific Reports, 10(1), 10739.

Renner, S. C., Baur, S., Possler, A., Winkler, J., Kalko, E. K. V., Bates, P. J. J., \& Mello, M. A. R. (2012). Food preferences of winter bird communities in different forest types. PLoS One, 7(12), e53121.

Renner, S. C., Gossner, M. M., Kahl, T., Kalko, E. K. V., Weisser, W. W., Fischer, M., \& Allan, E. (2014). Temporal changes in randomness of bird communities across central Europe. PLoS One, 9(11), el12347.

Sanderson, F. J., Kucharz, M., Jobda, M., \& Donald, P. F. (2013). Impacts of agricultural intensification and abandonment on farmland birds in Poland following EU accession. Agriculture, Ecosystems and Environment, 168, 16-24.

Saunders, D. A., Hobbs, R. J., \& Margules, C. R. (1991). Biological consequences of ecosystem fragmentation: A review. Conservation Biology, 5(1), 18-32.

Shimadzu, H., Dornelas, M., \& Magurran, A. E. (2015). Measuring temporal turnover in ecological communities. Methods in Ecology and Evolution, 6(12), 1384-1394.

Shutt, J. D., Cabello, I. B., Keogan, K., Leech, D. I., Samplonius, J. M., Whittle, L., Burgess, M. D., \& Phillimore, A. B. (2019). The environmental predictors of spatio-temporal variation in the breeding phenology of a passerine bird. Proceedings of the Royal Society B: Biological Sciences, 286(1908), 952.

Shvidenko, A., Buksha, I., Krakovska, S., \& Lakyda, P. (2017). Vulnerability of Ukrainian forests to climate change. Sustainability, 9(7), 1152.

Sirami, C., Brotons, L., \& Martin, J.-L. (2006). Vegetation and songbird response to land abandonment: from landscape to census plot. Diversity and Distributions, $13(1), 42-52$.

Sokolov, S. G., \& Zhukov, A. V. (2014). Variation trends in the parasite assemblages of the Chinese sleeper Perccottus glenii (Actinopterygii: Odontobutidae) in its native habitat. Biology Bulletin, 41(5), $468-477$.

Sokolov, S. G., \& Zhukov, A. V. (2016). The diversity of parasites in the Chinese sleeper Perccottus glenii Dybowski, 1877 (Actinopterygii: Perciformes) under the conditions of large-scale range expansion. Biology Bulletin, 43(4), 374-383.

Sokolov, S. G., \& Zhukov, A. V. (2017). Functional diversity of a parasite assemblages of the Chinese sleeper Perccottus glenii Dybowski, 1877 (Actinopterygii: Odontobutidae) and habitat structure of the host. Biology Bulletin, 44(3), 331-336.

Spake, R., Soga, M., Kawamura, K., Cooke, R. S., Yamaura, Y., \& Eigenbrod, F. (2020). Regional variability in landscape effects on forest bird communities. Landscape Ecology, 35(5), 1055-1071.

Srinivasan, U., Elsen, P. R., \& Wilcove, D. S. (2019). Annual temperature variation influences the vulnerability of montane bird communities to land-use change. Ecography, 42(12), 2084-2094.
Srivastava, D. S., \& Vellend, M. (2005). Biodiversity-ecosystem function research: Is it relevant to conservation? Annual Review of Ecology, Evolution, and Systematics, 36(1), 267-294.

Stegen, J. C., Freestone, A. L., Crist, T. O., Anderson, M. J., Chase, J. M., Comita, L. S., Comell, H. V., Davies, K. F., Harrison, S. P., Hurlbert, A. H., Inouye, B. D., Kraft, N. J. B., Myers, J. A., Sanders, N. J., Swenson, N. G., \& Vellend, M. (2013). Stochastic and deterministic drivers of spatial and temporal turnover in breeding bird communities. Global Ecology and Biogeography, 22(2), 202-212.

Steiner, C. F., \& Leibold, M. A. (2004). Cyclic assembly trajectories and scale-dependent productivity-diversity relationships. Ecology, 85(1), 107-113.

Stouffer, P. C., Johnson, E. I., Bierregaard, R. O., \& Lovejoy, T. E. (2011). Understory bird communities in Amazonian rainforest fragments: Species turnover through 25 years post-isolation in recovering landscapes. PLoS One, 6(6), e20543.

Taylor, C., \& Lindenmayer, D. B. (2020). Temporal fragmentation of a critically endangered forest ecosystem. Austral Ecology, 45(3), 340-354.

Török, P., Dembicz, I., Dajić-Stevanović, Z., \& Kuzemko, A. (2020). Grasslands of Eastern Europe. In: Encyclopedia of the world's biomes. Elsevier. Pp. 703-713.

Vandandorj, S., Munkhjargal, E., Boldgiv, B., \& Gantsetseg, B. (2017). Changes in event number and duration of rain types over Mongolia from 1981 to 2014. Environmental Earth Sciences, 76(2), 70.

Veech, J. A., \& Crist, T. O. (2007). Habitat and climate heterogeneity maintain betadiversity of birds among landscapes within ecoregions. Global Ecology and Biogeography, 16(5), 650-656.

Vengosh, A. (2003). Salinization and saline environments. In: Treatise on Geochemistry. Elsevier. Pp. 1-35.

Visser, M. E., te Marvelde, L., \& Lof, M. E. (2012). Adaptive phenological mismatches of birds and their food in a warming world. Journal of Omithology, 153(S1), 75-84.

Vorovka, V.P., \& Demchenko, V. O. (2019). Hydroecological problems of dairy estuary in connection with the instable of its communication with the Azov Sea. Visnyk of V. N. Karazin Kharkiv National University Series Ecology, 21, 23-33.

Waide, R. B., Willig, M. R., Steiner, C. F., Mittelbach, G., Gough, L., Dodson, S. I., Juday, G. P., \& Parmenter, R. (1999). The relationship between productivity and species richness. Annual Review of Ecology and Systematics, 30(1), 257-300.

Wretenberg, J., Pärt, T., \& Berg, Å. (2010). Changes in local species richness of farmland birds in relation to land-use changes and landscape structure. Biological Conservation, 143(2), 375-381.

Zhang, J., Qian, H., Girardello, M., Pellissier, V., Nielsen, S. E., \& Svenning, J. C. (2018). Trophic interactions among vertebrate guilds and plants shape global patterns in species diversity. Proceedings of the Royal Society B: Biological Sciences, 285(1883), 949.

Zhukov, O. V., Bondarev, D. L., Yermak, Y. I., \& Fedushko, M. P. (2019). Effects of temperature patterns on the spawining phenology and niche overlap of fish assemblages in the water bodies of the Dnipro River basin. Ecologica Montenegrina, 22, 177-203.

Zymaroieva, A., Zhukov, O., Fedonyuk, T., \& Pinkina, T. (2020). The spatio-temporal trend of rapeseed yields in Ukraine as a marker of agro-economic factors influence. Agronomy Research, 18(S2), 119.

Zymaroieva, A., Zhukov, O., Romanchuck, L., \& Pinkin, A. (2019). Spatiotemporal dynamics of cereals grains and grain legumes yield in Ukraine. Bulgarian Journal of Agricultural Science, 25(6), 1107-1113. 